\title{
PENGARUH PERISTIWA GERAKAN 30 SEPTEMBER 1965 TERHADAP KONDISI SOSIOPSIKOLOGIS MASYARAKAT KELURAHAN WUNGU KECAMATAN WUNGU KABUPATEN MADIUN 1965-1998
}

\author{
Mathory Aquarta \& Soebijantoro*
}

\begin{abstract}
Abstrak
Penelitian ini bertujuan untuk mengetahui pengaruh peristiwa gerakan 30 September 1965 terhadap kondisi psikologi sosial masyarakat Kelurahan Wungu Kecamatan Wungu Kabupaten Madiun pada tahun 1965-1998. Selain itu peneliti juga ingin mengetahui bagaimana pengaruh peristiwa tersebut dalam aspek ekonomi. Berdasarkan hasil penelitian dapat diketahui bahwa pengaruh peristiwa gerakan 30 September 1965 terhadap kondisi psikologi sosial masyarakat Kelurahan Wungu Kecamatan Wungu Kabupaten Madiun pada tahun 1965-1998, adalah adanya beberapa warga masyarakat Kelurahan Wungu yang ikut menjadi tahanan politik dan menghilang setelah ditangkap oleh intel tentara pemerintah. Mayoritas warga masyarakat yang terdiri dari petani dan pedagang saat itu masih berpendidikan rendah sehingga mudah didekati oleh oknum-oknum PKI Muncul rasa takut dan was-was pada sebagian besar warga masyarakat Kelurahan Wungu karena takut disebut atau dituduh sebagai anggota PKI. Pada masa Orba, warga Kelurahan Wungu rasa takut dan was-was ini masih sangat besar ketika bertemu tentara, polisi, dan orang asing yang tidak dikenal. Hingga masa sekarang masih ada rasa takut pada sebagian warga apabila diwawancara yang berhubungan dengan sejarah PKI di Kelurahan Wungu.
\end{abstract}

Kata kunci: Gerakan 30 September 1965, Sosiopsikologis

\section{Pendahuluan}

Indonesia merupakan salah satu negara yang dalam sejarah memiliki keragaman ideologi pemikiran. Keragaman ideologi dapat dilihat dari munculnya banyak partai politik pada masa Indonesia masih dalam kekuasaan Belanda dan Jepang maupun setelah Indonesia memproklamasikan kemerdekaan Indonesia lewat proklamasi yang dibacakan oleh Soekarno-Hatta pada tanggal 17 Agustus 1945.

Salah satu faham yang sangat besar pengaruhnya dengan sejarah Indonesia adalah paham komunis. Dalam sejarah tertulis 3 peristiwa pemberontakan besar yang dilatar belakangi oleh tokoh-tokoh penganut paham komunis, yaitu

pemberontakan komunis pada tahun 1926;

(2) pemberontakan komunis Madiun 1948; dan (3) gerakan 30 September 1965.

Lahir dan berkembangnya gerakan komunis di Indonesia tidak dapat dipisahkan dari sebuah organisasi yang bernama ISDV (Indische Sociaaldemocratische Vereeniging). Organisasi kaum sosialis Belanda yang pada mulanya merupakan klub debat kecil diantara sesama anggota mereka. Klub ini didirikan oleh Hendricus Josephus Fransiscus Marie Sneevliet di Semarang pada bulan Mei 1914 (Takashi Shiraishi, 1997: 133). Karena anggotanya mayoritas adalah orang-orang Eropa, Sneevliet dan kawan-kawannya merasa sangat sulit untuk mengembangkan 
organisasi tersebut, karena orang pribumi bersifat antipati terhadap nama yang berbau Eropa. Oleh karena itu, mereka berupaya untuk bersekutu dengan gerakan yang lebih besar dan yang dapat bertindak sebagai jembatan kepada massa rakyat Indonesia (Marwati Djoened Poesponegoro dkk, 1993: 356).

Masyarakat umum lebih mengenal Kelurahan Wungu dengan sebutan "Dungus”. Dalam sejarah, sebutan "Dungus” berasal dari ibukota Distrik Kanigoro (PEMKAB MADIUN, 1980: 312). Dungus juga menjadi rute pelarian tentara FDR yang terdesak oleh pasukan Siliwangi karena letaknya yang berada di lereng Gunung Wilis, sembilan kilometer dari Madiun, merupakan posisi yang kuat untuk bertahan, dengan daerah penunjang di belakang yang ideal untuk bergerilya (Harry A. Poeze, 2011: 224).

Hubungan antara "Dungus" dengan komunis berlanjut pada peristiwa gerakan 30 September 1965. PKI yang saat itu merupakan partai dengan jumlah anggota yang besar melakukan pemberontakan yang gagal. Peristiwa ini sering disebut dengan Peristiwa gerakan 30 September 1965. Peristiwa gerakan 30 September 1965 di Jakarta dan Yogyakarta ini menyebabkan ditangkapnya ribuan anggota dan simpatisan PKI oleh Pemerintah RI. Dalam hal ini "Dungus" dijadikan tempat penahanan sementara para tawanan anggota PKI oleh Pemerintah RI. Warga masyarakat "Dungus" yang diduga merupakan anggota atau simpatisan PKI juga ikut ditahan Interaksi antara masyarakat "Dungus" dengan para tahanan yang di tawan di bangunan distrik Dungus tak dapat dihindarkan, karena tempat tinggal warga dengan lokasi distrik yang berdekatan. Keragaman pemikiran dan persepsi yang ada di masyarakat "Dungus" muncul disebabkan banyak warga masyarakat yang berinteraksi langsung dengan para tahanan.

Peristiwa gerakan 30 September 1965 dengan berbagai dampaknya telah banyak dibicarakan dan ditulis, baik oleh pakar dalam negeri maupun luar negeri dengan berbagai dimensi, namun kiranya belum ada yang secara khusus meneliti bagaimana pengaruh peristiwa gerakan 30 September 1965 terhadap kondisi psikologi sosial masyarakat di Kelurahan Wungu.

Oleh karena itu pengaruh peristiwa gerakan 30 September 1965 terhadap kondisi psikologi sosial masyarakat di Kelurahan Wungu menarik untuk dikaji secara mendalam karena memiliki keunikan dan kekhasan jika dibandingkan dengan daerah lain.

Berdasarkan latar belakang masalah tersebut di atas, maka dapat dirumuskan permasalahan, "Bagaimana pengaruh peristiwa gerakan 30 September 1965 terhadap kondisi psikologi sosial masyarakat Kelurahan Wungu Kecamatan 
Wungu Kabupaten Madiun pada tahun 1965-1998?"

\section{Tinjauan Pustaka}

Pada tanggal 30 September malam, satu batalyon pengawal istana yang dipimpin oleh Letnan Kolonel Untung (sebelumnya dari Divisi Diponegoro), satu batalyon dari Divisi Diponegoro, satu batalyon dari Divisi Brawijaya, dan orangorang sipil dari Pemuda Rakyat PKI meninggalkan pangkalan udara Halim. Mereka pergi untuk menculik Nasution, Yani, Parman, dan empat orang jendral angkatan darat lainnya dari rumah-rumah mereka di Jakarta (C. Ricklefs, 2008: 553).

Secara fisik militer gerakan dipimpin oleh Letnan Kolonel Untung, Komandan Batalyon I Resimen Cakrabirawa (Pasukan Pengawal Presiden) selaku pimpinan formal seluruh gerakan. mereka mulai bergerak pada dini hari tanggal 1 Oktober 1965, didahului dengan gerakan penculikan dan pembunuhan terhadap enam perwira pertama Angkatan Darat. Kesemuanya dibawa ke Desa Lubang Buaya. Mereka dianiaya dan akhirnya dibunuh oleh anggota-anggota Pemuda Rakyat, Gerwani, dan lain-lain organisasi satelit PKI. semua jenasah lalu dimasukkan ke dalam sebuah sumur tua lalu ditimbun dengan sampah dan tanah (Marwati Djoened Poesponegoro dkk, 2008: 483-484).

Keenam pejabat tinggi yang dibunuh tersebut adalah:
1. Letjen TNI Ahmad Yani (Menteri/Panglima Angkatan Darat/Kepala Staf Komando Operasi Tertinggi)

2. Mayjen TNI Raden Suprapto (Deputi II Menteri/Panglima AD bidang Administrasi)

3. Mayjen TNI Mas Tirtodarmo Haryono (Deputi III Menteri/Panglima AD bidang Perencanaan dan Pembinaan)

4. Mayjen TNI Siswondo Parman (Asisten I Menteri/Panglima AD bidang Intelijen)

5. Brigjen TNI Donald Isaac Panjaitan (Asisten IV Menteri/Panglima AD bidang Logistik)

6. Brigjen TNI Sutoyo Siswomiharjo (Inspektur Kehakiman/Oditur Jenderal Angkatan Darat)

Jenderal TNI Abdul Harris Nasution yang menjadi sasaran utama, selamat dari upaya pembunuhan tersebut. Sebaliknya, putrinya Ade Irma Suryani Nasution dan ajudan beliau, Lettu CZI Pierre Andreas Tendean tewas dalam usaha pembunuhan tersebut. Turut tewas adalah Bripka Karel Satsuit Tubun (Pengawal kediaman resmi Wakil Perdana Menteri II dr.J. Leimena) karena mengadakan perlawanan saat akan dilucuti oleh penculik yang akan masuk kerumah jendral A.H Nasution (Marwati Djoened Poesponegoro dkk, 2008: 484).

Bersama dengan gerakan penculikan, pasukan G-30-S/PKI juga menguasai objek vital yaitu Studio RRI Pusat di Jalan Medan Merdeka Barat, dan gedung PN 
Telekomunikasi di Jalan Medan Merdeka Selatan. Melalui RRI yang telah mereka kuasai, pada pukul 07.20 dan diulang pada pukul 08.15, Letnan Kolonel Untung menyiarkan pengumuman tentang Gerakan 30 September. Antara lain diumumkan bahwa gerakan mereka ditujukan kepada jendral-jendral anggota Dewan Jendral yang akan mengadakan kudeta (Marwati Djoened Poesponegoro dkk, 2008: 484).

Pada tanggal 1 Oktober 1965 itu ada 2 surat kabar yang memuat berita G-30-S menyelamatkan Pemimpin Besar Revolusi dan memuat nama-nama anggota Dewan Revolusi, yaitu Harian Rakjat dan Warta Bhakti. Dalam kolom "film minggu ini", Harian Rakjat memuat karikatur lakon, the General's fall (Marwati Djoened Poesponegoro dkk, 2008: 484).

Mereka memngumumkan bahwa G30-S dilancarkan oleh perwira-perwira yang "berpikiran maju", menentang rencana kudeta Dewan Jendral. Pada pukul 13.00 disiarkan sebuah dekrit tentang pembentukan Dewan Revolusi, dan Kabinet Dwikora dinyatakan demisioner. Diumumkan pula bahwa Dewan Revolusi merupakan sumber kekuasaan dalam Negara Republik Indonesia (Marwati Djoened Poesponegoro dkk, 2008: 484485).

Dengan demikian dapat ditarik kesimpulan bahwa Gerakan 30 September 1965 di Jakarta adalah suatu gerakan penculikan dan pembunuhan para Jendral senior Angkatan Darat oleh pasukan Cakrabhirawa yang dipimpin Letkol Untung, yang setelah itu juga menguasai objek-objek vital di antaranya RRI dan Kantor telekomunikasi.

Di Jawa Tengah G $30 \mathrm{~S} / \mathrm{PKI}$ juga bergerak dibawah pimpinan Kolonel Sahirman. Dia menyatakan mendukung G 30 S/PKI di Jakarta dan menyatakan sebagai Komandan G 30 S/PKI daerah Tingkat I Jawa Tengah. Kemudian mereka menguasai markas Kodam VII/Diponegoro. Gerakan tersebut meluas ke daerah dengan menguasai Markas Komando Resort Militer 071/Purwokerto, Markas Komando Resort Militer 072/Yogyakarta, Markas Komando Resort Militer 073/Salatiga dan Markas Brigade Infanteri 6 Surakarta. Mayor Mulyono mengambil alih Markas Komando Resort Militer 072/Yogyakarta, serta menculik Komandan Korem 072 Kolonel Katamso dan Kepala Staf Korem 072 Letkol Sugiyono. Kedua pimpinan Korem tersebut dibawa di markas batalyon L, Kentungan sebelah utara Yogyakarta, kemudian dibunuh disana (Marwati Djoened Poesponegoro dkk, 2008: 490-492).

Di kota Solo, dengan mempergunakan kekuatan batalyon $M$ pada tanggal 1 Oktober 1965, G-30-S/PKI bergerak mengadakan penculikan terhadap Komandan Brigade 6 Kolonel Azahari, Letkol Prawoto, Letkol Ezi Soeharto, Mayor Soeparjan, Kapten Prawoto, dan Mayor Darso. Mereka menduduki gedung RRI, 
Telekomunikasi, Bank Negara, dan mengumumkan dukungan kepada G-30-S. Tanggal 2 Oktober 1965 Wali Kota Solo Oetomo Ramelan melalui RRI mengumumkan dukungannya kepada G-30S (Marwati Djoened Poesponegoro dkk, 2008: 492).

Dengan demikian dapat ditarik kesimpulan bahwa Gerakan 30 September 1965 di Jawa Tengah adalah suatu gerakan dukungan kepada Gerakan 30 September di Jakarta dengan menguasai Kodam VII/Diponegoro oleh pasukan dibawah pimpinan Kolonel Sahirman, yang setelah itu juga menguasai objek-objek vital di antaranya RRI dan Gedung telekomunikasi dan Bank Negara sedangkan di Surakarta, Wali Kota Solo Oetomo Ramelan melalui RRI juga mengumumkan dukungannya kepada G-30-S.

Psikologi merupakan kata yang diambil dari bahasa Belanda "psycologie" atau dari bahasa Inggris " psychology". Ditinjau dari sudut asal katanya, kata psycologie dan psychology berasal dari bahasa Yunani yang terdiri dari dua buah kata, yaitu "psyce" dan "logos" yang berarti jiwa dan ilmu. Berdasarkan kedua pengertian itu, maka orang dengan mudah memberikan batasan atau pengertian psikologi sebagai ilmu pengetahuan tentang jiwa atau sering disebut dengan "ilmu jiwa" (Gerungan, 2004: 1).

Psikologi dalam konteks penelitian ini berkenaan dengan psikologi sosial. yang dimaksud psikologi sosial menurut Watson, merupakan studi tentang interaksi manusia, sedangkan pendapat Krech, Chruthfield, dan Balami, psikologi sosial adalah pengetahuan hubungan perilaku interaksi manusia (Muhammad Hanif, 2011: 63).

Pendapat Baron dan Bryne (2004) psikologi sosial adalah cabang psikologi yang berupaya untuk memahami dan menjelaskan cara berfikir, berperasaan, dan berperilaku individu yang dipengaruhi oleh kehadiran orang lain. Kehadiran orang lain itu dapat dirasakan secara langsung, diimajinasikan, ataupun diimplikasikan (Fattah Hanurawan, 2010: 1).

Kimball Young (dalam Slamet Santoso, 2010: 9) menyatakan bahwa "Social psikologi is sciencitific study interaction between individu and individu, individu and group, and group and group" (Psikologi sosial adalah studi tentang proses interaksi individu manusia). Sedangkan Myers berpendapat bahwa psikologi sosial adalah ilmu yang mempelajari pengaruh situasisituasi kita, khususnya bagaimana kita memandang dan mempengaruhi satu sama lain (David G Myers, 2012: 5).

Dari beberapa pendapat diatas dapat ditarik benang merah bahwa psikologi sosial merupakan kajian tentang proses interaksi masyarakat. Dalam arti luas, interaksi mengacu kepada kenyataan bahwa respon seseorang seorang individu atau kelompok (isyarat, ucapan atau gerak jasmaniyah) merupakan stimulus bagi 
individu atau kelompok lainnya yang sebaliknya merespon individu atau kelompok pertama (Waseso dalam Muhammad Hanif, 2011: 63).

$$
\text { Pendapat senada disampaikan }
$$
Gerungan (dalam Muhammad Hanif, 2011: 63) bahwa interaksi sosial merupakan suatu hubungan antara dua atau lebih individu manusia, dimana kelakuan individu yang satu mempengaruhi, mengubah, atau memperbaiki kelakuan individu yang lain, atau sebaliknya.

Pendapat para tokoh tentang pengertian psikologi sosial di atas sangat beragam. Namun demikian tidaklah berarti antara yang satu dengan yang lainnya saling bertentangan. Perpaduan diantara pendapat tersebut akan dapat saling melengkapi dan menyempurnakan. Rangkuman pengertian dari berbagai pendapat tersebut dapat dirumuskan sebagai berikut : "Psikologi sosial adalah suatu studi ilmiah tentang pengalaman dan tingkah laku individuindividu dalam hubungannya dengan situasi sosial." Dengan demikian membicarakan psikologi sosial tidak dapat dilepaskan dari pembicaraan individu yang berhubungan dengan situasi-situasi sosial.

Dengan demikian dapat ditarik kesimpulan bahwa psikologi sosial adalah cabang ilmu psikologi yang berusaha memahami dan menjelaskan cara berfikir, berperasaan, dan berperilaku manusia baik secara individu maupun kelompok yang dipengaruhi oleh kehadiran orang lain.
Krech, Crutchfield dan Ballachey (dalam Elly M. Setiadi dkk, 2004: 79) mengemukakan definisi masyarakat sebagai "a society is that it is an organized collectivity of interacting people whose activities become centered around a set of common goals, and who tend to share common believe, attitudes, and of action." (masyarakat adalah sekumpulan yanng terorganisir dari orangorang yang berinteraksi yang mana kegiatannya berpusat pada tujuan bersama, dan yang mana cenderung untuk berbagi mengenai percaya, sikap, dan tindakan).

Pendapat Durkheim tentang masyarakat adalah system yang mengikat kehidupan orang-orang dan merupakan lingkungan yang menguasai segala kehidupan (Gerungan, 2004: 39).

Fairchild dalam konsepnya menyatakan bahwa:"society is a group human beings cooperating in the pursuit of several of their major interest, invariably including self maintenance and selfperpetuation, the concept of society includes continuity, complex associational relationships, and a composition including representatives of fundamental human types, specifically men, women, and children" (masyarakat adalah sekelompok manusia yang bekerja sama dalam mengejar beberapa kepentingan utama mereka, termasuk memelihara diri dan kelangsungan hidup, konsep masyarakat termasuk kesinambungan, hubungan asosiasional yang kompleks, dan komposisi 
termasuk perwakilan dari jenis manusia yang mendasar, khususnya laki-laki, wanita, dan anak-anak) (dalam Elly M. Setiadi dkk, 2004: 80).

Horton dan Hunt berpendapat bahwa: " a society is a relatively independent, selfperpetuating human group who occupy territory, share a culture, and have most their association within this group" (masyarakat adalah relatif independen, sekelompok manusia mengabadikan diri menempati wilayah, berbagi budaya, dan memiliki sebagian besar hubungan mereka dalam kelompok ini) (dalam Elly M. Setiadi dkk, 2004: 80).

Di antara istilah (konsep) masyarakat yang telah dikemukakan di atas, tidak ada perbedaan ungkapan yang mendasar, justru yang ada yaitu mengenai persamaannya. Jadi dapat disimpulkan bahwa masyarakat adalah kumpulan orang yang di dalamnya hidup bersama dalam waktu yang cukup lama. Yang utama, masyarakat itu merupakan kelompok atau kolektivitas manusia yang melakukan antar hubungan, sedikit banyak bersifat kekal, berlandaskan perhatian dan tujuan bersama, serta telah melakukan jalinan secara berkesinambungan dalam waktu yang relatif lama.

\section{Tujuan dan Manfaat Penelitian}

Tujuan penelitian ini adalah untuk mengetahui pengaruh peristiwa gerakan 30 September 1965 terhadap kondisi psikologi sosial masyarakat Kelurahan Wungu pada tahun 1965-1998.

Langkah ini penting dilakukan sebagai wujud kesediaan peneliti untuk menilai kondisi psikologi sosial masyarakat Kelurahan Wungu, serta sikap, kebijakan, dan perilaku sekarang dan masa yang akan datang.

Hasil penelitian ini diyakini dapat bermanfaat bagi beberapa pihak, yakni:

1. Bagi Peneliti

a. Sebagai calon guru mata pelajaran sejarah penelitian ini dapat menambah wawasan pengetahuan baru mengenai sejarah lokal di Madiun.

b. Dapat menjadi bahan pertimbangan baru lebih lanjut demi pembangunan ilmu pengetahuan.

2. Bagi Program Studi Pendidikan Sejarah FPIPS IKIP PGRI Madiun

a. Dapat memberikan sumbangan pikiran yang sekiranya untuk dijadikan bahan pertimbangan dalam meningkatkan kualitas pendidikan.

b. Dapat memberikan sumbangan penelitian yang dijadikan bahan pertimbangan dalam meningkatkan kesadaran sejarah.

3. Bagi Masyarakat

Dapat memberikan gambaran tentang kondisi sosial masyarakat di Kelurahan Wungu pasca G 30 S, konflik sosial, dan dimungkinkan dapat meningkatkan 
kesadaran sejarah bagi masyarakat terutama generasi muda.

\section{Metode Penelitian}

Jenis penelitian yang digunakan adalah jenis studi kasus. Dimana Husaini Usman mengemukakan bahwa penelitian kasus adalah penelitian yang digunakan untuk mempelajari latar belakang keadaan sekarang, dan interaksi suatu sosial, individu, kelompok, lembaga dan masyarakat (Husaini Usman, 2004:5). Penelitian yang menggunakan jenis penelitian studi kasus ini dapat membantu peneliti dalam mengungkap masalah yang terjadi dalam kehidupan masyarakat sebagai akibat dari proses interaksi sosial dalam kehidupan bermasyarakat.

1. Tempat dan Waktu Penelitian

Lokasi atau tempat penelitian ini dilaksanakan di Kelurahan Wungu Kecamatan Wungu Kabupaten Madiun. Kelurahan Wungu merupakan kelurahan yang letaknya sekitar $14 \mathrm{~km}$ dari Kota Madiun. Di kelurahan ini merupakan kelurahan yang bisa dikatakan cukup maju baik dilihat dari keadaan sosial maupun ekonomi masyarakatnya, hal ini dibuktikan sebagian masyarakatnya sudah memiliki lapangan pekerjaan yang mapan. Masyarakat umum lebih mengenal Kelurahan Wungu dengan sebutan "Dungus". Dalam sejarah, sebutan "Dungus" berasal dari ibukota Distrik Kanigoro. Bekas kantor Distrik Kanigoro yang masih berdiri menunjukkan hal tersebut. Kantor Distrik Kanigoro ini juga menjadi saksi bisu penahanan para tawanan yang diduga merupakan anggota maupun simpatisan PKI Di Madiun. Penelitian dilakukan pada bulan Agustus 2013 hingga Januari 2014. Peneliti membutuhkan waktu enam bulan untuk melakukan penelitian di lapangan agar memperoleh informasi yang relevan.

2. Sumber Data Penelitian

Sumber data yang digunakan dalam penelitian ini adalah sumber data primer dan sumber data sekunder. Data primer berupa keterangan atau fakta dilokasi penelitian yang diperoleh dari informan dan aktivitas yang berkaitan dengan pengaruh peristiwa gerakan 30 September 1965 terhadap kondisi psikologi sosial masyarakat Kelurahan Wungu pada tahun 1965-1998, sedangkan data sekunder berupa dokumen dan arsip tentang subjek penelitian yaitu dokumen sejarah dan profil objek, dan data lain yang relevan.

3. Informan

Dalam hal ini peneliti mengambil beberapa informan agar mendapatkan informasi berupa data-data yang relevan seperti masyarakat Kelurahan Wungu yang sejaman dengan peristiwa Gerakan 30 September 1965.

4. Pengambilan Data

Penganbilan data peneliti menggunakan teknik wawancara, observasi, dan pencatatan dokumentasi. 
5. Analisis Data

Pengumpulan data merupakan jantung penelitian kualitatif dan analisis data merupakan jiwanya. Analisis data merupakan proses mengorganisasikan dan mengurutkan data ke dalam pola, kategori dan satuan uraian dasar sehingga dapat ditemukan tema dan dapat dirumuskan hipotesis seperti yang didasarkan oleh data (Basrowi dan Suwandi, 2008 :91). Dalam proses analisis data terdapat tiga komponen yang harus dipahami dan diperhatikan oleh setiap peneliti, khususnya pada penelitian kualitatif. Tiga komponen tersebut adalah:
a. Reduksi Data
b. Penyajian Data Atau Display Data
c. Penarikan Kesimpulan Atau Tahap Penemuan Hasil

Dalam menganalisis data, peneliti menggunakan analisis kualitatif model interaktif (Sutopo, 1990) sebagaimana bagan di bawah ini

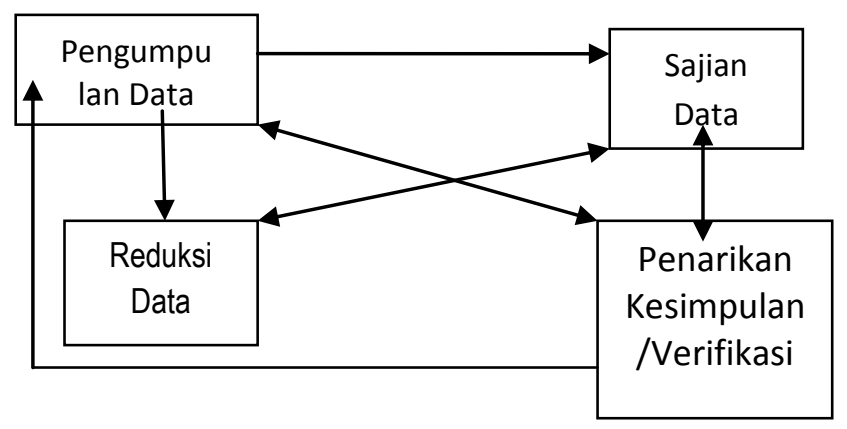

Bagan 1: Model Analisis Interaktif

\section{Hasil Penelitian}

Kelurahan Wungu merupakan Kelurahan yang tidaklah masuk dalam Kelurahan yang tertinggal karena melihat akses jalan yang sudah sangat baik guna mendukung transportasi masyarakat sekitar. Kelurahan Wungu secara geografis sangatlah mudah dijangkau semua orang, hal ini disebabkan oleh letak desa yang merupakan jalur transit antar desa tetangga yang berbatasan dengan Kelurahan Wungu seperti Desa Brumbun, Desa Kresek, Desa Banjar Sari Kulon, dan Desa Kuwiran. Orbitasinya adalah $8 \mathrm{Km}$ dari Ibukota Kecamatan, $14 \mathrm{Km}$ dari Ibukota Kabupaten, dan 180 Km dari Ibukota Propinsi.

Kelurahan Wungu dibatasi oleh sebelah utara berbatasan dengan hutan Mojorayung, sebelah selatan berbatasan dengan Desa Brumbun dan Kresek, sebelah timur berbatasan dengan Desa Kuwiran (Kecamatan Kare) sebelah barat berbatasan dengan Desa Banjar Sari Kulon (Kecamatan Dagangan) (sumber data: Profil Kelurahan Wungu 2012), dan luas keseluruhan wilayah Kelurahan Wungu memiliki luas wilayah kurang lebih 1307,170 ha. Ketinggian tanah dari permukaan laut $224 \mathrm{~m}$ dengan topografi dataran pegunungan (Sumber: Data Profil Kelurahan Wungu, 2012).

A. Pengaruh Peristiwa Gerakan 30 September 1965 Terhadap Kondisi Psikologi Sosial Masyarakat Kelurahan Wungu.

Gerakan $\quad 30 \quad$ September 1965 mengakibatkan ketakutan pada warga yang pernah berhubungan dengan organisasiorganisasi PKI. Timbul suasana mencekam yang diakibatkan oleh penangkapan 
beberapa warga Kelurahan Wungu oleh intel Pemerintah. Warga yang dulunya pernah menjadi anggota PKI banyak yang meminta perlindungan kepada para Pamong Desa terutama kepada Kepala Desa saat itu Mariyono (wawancara dengan Supeni, 30 November 2013).

Dengan adanya gerakan 30 September di Jakarta dan Jawa Tengah mengakibatkan pemerintah pusat membentuk Kopkamtib untuk memulihkan keamanan. Salah satunya programnya adalah dengan pembersihan anggota PKI di seluruh wilayah Indonesia (wawancara dengan Sugiri, 15 November 2013). Kelurahan Wungu dijadikan kamp penahanan para tapol PKI. "Para tapol itu ditahan di Distrik", ujar Sugiri. Sugiri pada saat itu mendapat tugas untuk ikut berjaga di luar gedung distrik.

"Para tahanan diangkut oleh truk tentara untuk kemudian mereka di tempatkan di Distrik", kata Sugiri (wawancara dengan Sugiri, 15 November 2013). Sugiri menambahkan bahwa para tahanan ini mayoritas bukan orang sekitar Dungus. Dalam satu hari biasanya ada truk yang keluar masuk untuk mengangkut para tahanan ini. Saat di tanya tentang nasip para tahanan ini, Sugiri menjawab bahwa mereka semua mayoritas akan dieksekusi mati. Tetapi ada 2 tahanan yang selamat yaitu seorang perempuan yang berwajah cantik yang akhirnya di sunting oleh salah satu tentara dan seorang laki-laki yang lolos saat akan dieksekusi di Jurang Uni Grape dengan cara meloncat kedalam jurang.

Hal di atas juga di benarkan oleh Djumani, Kitin, dan Paiman (wawancara dengan Djumani, 29 November 2013). Mereka menyatakan bahwa memang ada tahanan yang berhasil lolos di Jurang Uni karena adanya pertolongan Tuhan. Sebab peluang untuk lolos dari eksekusi memang sangatlah kecil sekali.

Sebagai tempat mengeksekusi para tahanan, telah dipersiapkan oleh aparat yaitu di hutan utara Dusun Temulus dan Jurang Uni Grape (wawancara dengan Sugiri, 15 November 2013). "Biasanya truk tentara berpencar kearah timur (Jurang Uni) dan barat (Temulus)"kata Sugiri. Hal ini diyakini oleh Kasimun dan Mudzakir. Alasan Kasimun (wawancara dengan Kasimun, 29 November 2013) ialah karena ia pernah ikut rombongan tentara baik ke Jurang Uni maupun ke Temulus untuk melihat proses eksekusi. Tentang tahanan yang berhasil lolos ia membenarkan karena saat itu ia ikut melihat proses eksekusi di Jurang Uni dan melihat tahanan yang lolos itu dengan mata kepala sendiri. Sedangkan pendapat Djumani dan Paiman, selain 2 tempat diatas masih ada 2 lokasi lagi yang dipergunakan sebagai tempat eksekusi yakni : songo-songo dan timur Cao sehingga total ada 4 tempat eksekusi para tahanan PKI (wawancara dengan Djumani, 29 November 2013). 
Untuk proses eksekusi, biasanya algojo memakai alat yang terbuat dari besi yang berat dan bentuknya seperti linggis (wawancara dengan Kasimun, 29 November 2013). Para tahanan akan dipukul tengkuknya sampai mati. Sedangkan menurut kesaksian Supeni dan Kitin, para algojo ada yag membawa pedang panjang (wawancara dengan Supeni, 30 November 2013) sehingga membuat warga yang melihat merasa ngeri dan takut.

Jumlah tahanan di Distrik menurut Sugiri sekitar 1000 orang. Hal ini di dasarkan pada seringnya aktifitas keluar masuk truk tentara yang mengangkut para tahanan di Distrik dan jangka waktu penggunaan gedung Distrik sebagai kamp tahanan yaitu kira-kira 3 bulan (wawancara dengan Sugiri, 15 November 2013). Kapasitas Distrik yang hanya mampu menampung sekitar 30-50 orang tahanan membuat para tahanan ini berjejalan di ruang Distrik. Terdapat pemisahan antara tahanan lelaki dan tahanan perempuan. "Jika gedung sudah kosong karena tahanan sudah keluarkan maka segera akan diisi kembali dengan tahanan baru" kata Sugiri.

Jumlah tahanan di distrik menurut Kasimun berbeda dengan penuturan Sugiri (wawancara dengan Kasimun, 29 November 2013). Kasimun mengatakan bahwa tahanan kira-kira hanya sekitar 500 orang saja. Sedangkan Supeni menyebutkan jumlah sekitar 600-700 orang yang ditahan di Distrik (wawancara dengan Supeni, 30 November 2013).

Untuk suplai makanan bagi tahanan dan tentara di Distrik maka dibuat dapur umum di rumah Lurah Mariyono (wawancara dengan Supeni, 30 November 2013). "Setiap hari kira-kira setengah kwintal beras dimasak untuk kebutuhan Distrik" ujar Supeni. Hal ini di amini oleh Sugiri, Kasimun, Djumani, dan Kitin. Djumani menambahkan bahwa selain rumah Lurah Mariyono, rumah Gimun yang berada di sebelah barat Distrik juga di jadikan dapur umum (wawancara dengan Djumani, 29 November 2013).

Pendapat senada juga disampaikan oleh Djumani, Paiman, Kitin, dan Danus. Mereka mengatakan bahwa banyak warga yang meminta perlindungan kepada Kepala Desa Mariyono agar tidak ikut ditangkap (wawancara dengan Djumani, 29 November 2013). "Jika Lurahnya bukan Mariyono, niscaya Dungus habis warganya diambil intel", kata Djumani.

Ketakutan saat itu mengakibatkan warga apabila melewati distrik maka akan berjalan di sebelah selatan dan tanpa berani menengok ke arah gedung distrik di sebelah utara jalan yang ditempati tahanan PKI. Alasan warga ialah takut apabila terdapat tahanan yang mengenal mereka dan kemudian akan memanggil warga yang lewat. Apabila ada warga yang di panggil oleh tahanan dan member tanggapan, maka ini dapat dijadikan alasan untuk intel 
menangkap warga yang lewat tadi (wawancara dengan Djumani, 29 November 2013).

Suasana mencekam ini juga diakibatkan adanya jam malam bagi warga di Kelurahan Wungu, yaitu antara jam 11 malam sampai jam 04 pagi (wawancara dengan Djumani, 29 November 2013). Hal ini di benarkan oleh Sugiri, Paiman, Ponidi, dan Samingun. Mereka menyatakan bahwa tiap malam warga harus di dalam rumah kecuali yang mendapat tugas membantu di Distrik.

Tetapi hal ini dibantah oleh Kasimun yang mengatakan bahwa suasana di Kelurahan Wungu aman dan terkendali (wawancara dengan Kasimun, 29 November 2013). Kasimun mengatakan bahwa warga bersikap biasa-biasa saja dan menjalankan aktifitas seperti biasa tanpa adanya rasa ketakutan berlebihan.

Setelah keadaan dinyatakan aman maka operasi penumpasan PKI di Kelurahan Wungu pada khususnya di hentikan. Warga di Kelurahan Wungu mulai melakukan aktifitas sehari-hari seperti biasanya sebelum ada Gerakan 30 September 1965 dan operasi penumpasan PKI. Suasana aman dan tentram ini membuat roda kegiatan berjalan semestinya. Hal ini di sampaikan Kasimun (wawancara dengan Kasimun, 29 November 2013)yang menyatakan bahwa tidak ada perasaan takut dan was-was pada warga di Kelurahan Wungu. Hal senada juga dinyatakan oleh Sugiri (wawancara dengan
Sugiri, 15 November 2013). Sugiri menyatakan bahwa masyarakat di Kelurahan Wungu sudah tenang dan tentram setelah PKI di bubarkan.

Hal ini berkebalikan dengan pernyataan Djumani dan Paiman (wawancara dengan Djumani, 29 November 2013). Mereka sepakat bahwa masyarakat di Kelurahan Wungu terutama masyarakat kecil masih trauma pada kejadian di Distrik. Muncul rasa takut pada tentara maupun polisi karena mereka menganggap tentara dan polisi adalah pihak yang bertanggung jawab atas penculikan warga saat penumpasan PKI berlangsung. Muncul juga rasa was-was jika bertemu dengan orang asing karena mereka menganggap bahwa orang asing tersebut adalah intel pemerintah yang dikirim untuk mematamatai kegiatan warga.

Hal ini dibenarkan oleh Mudzakir (wawancara dengan Mudzakir, 10 November 2013) yang kemudian menambahi bahwa eks tapol dan keluarganya akan dipersulit dalam mencari pekerjaan sebagai Pegawai Negeri Sipil. Selain itu, eks tapol juga wajib absen di koramil minimal 1 bulan sekali selama di perlukan. Sependapat dengan itu, Danus (wawancara dengan Danus, 29 November 2013) menambahi bahwa di Koramil terdapat catatan-catatan lengkap tentang siapa saja warga yang menjadi daftar tapol PKI. 


\section{Pembahasan}

Gerakan $\quad 30 \quad$ September 1965 mengakibatkan ketakutan pada warga yang pernah berhubungan dengan organisasiorganisasi PKI. Timbul suasana mencekam yang diakibatkan oleh penangkapan beberapa warga Kelurahan Wungu oleh intel Pemerintah. Warga yang dulunya pernah menjadi anggota PKI banyak yang meminta perlindungan kepada para Pamong Desa terutama kepada Kepala Desa saat itu Mariyono (Sumber: wawancara dengan Supeni, 30 November 2013).

Dengan adanya gerakan 30 September di Jakarta dan Jawa Tengah mengakibatkan pemerintah pusat membentuk Kopkamtib untuk memulihkan keamanan. Salah satunya programnya adalah dengan pembersihan anggota PKI di seluruh wilayah Indonesia (Sumber: wawancara dengan Sugiri, 15 November 2013). Kelurahan Wungu dijadikan kamp penahanan para tapol PKI. "Para tapol itu ditahan di Distrik", ujar Sugiri. Sugiri pada saat itu mendapat tugas untuk ikut berjaga di luar gedung distrik.

Pendapat senada juga disampaikan oleh Djumani, Paiman, Kitin, dan Danus. Mereka mengatakan bahwa banyak warga yang meminta perlindungan kepada Kepala Desa Mariyono agar tidak ikut ditangkap (Sumber: wawancara dengan Djumani, 29 November 2013). "Jika Lurahnya bukan Mariyono, niscaya Dungus habis warganya diambil intel", kata Djumani. Ketakutan saat itu mengakibatkan warga apabila melewati distrik maka akan berjalan di sebelah selatan dan tanpa berani menengok ke arah gedung distrik di sebelah utara jalan yang ditempati tahanan PKI. Alasan warga ialah takut apabila terdapat tahanan yang mengenal mereka dan kemudian akan memanggil warga yang lewat. Apabila ada warga yang di panggil oleh tahanan dan member tanggapan, maka ini dapat dijadikan alasan untuk intel menangkap warga yang lewat tadi (Sumber: wawancara dengan Djumani, 29 November 2013).

Suasana mencekam ini juga diakibatkan adanya jam malam bagi warga di Kelurahan Wungu, yaitu antara jam 11 malam sampai jam 04 pagi (Sumber: wawancara dengan Djumani, 29 November 2013). Hal ini di benarkan oleh Sugiri, Paiman, Ponidi, dan Samingun. Mereka menyatakan bahwa tiap malam warga harus di dalam rumah kecuali yang mendapat tugas membantu di Distrik.

Tetapi hal ini dibantah oleh Kasimun yang mengatakan bahwa suasana di Kelurahan Wungu aman dan terkendali (Sumber: wawancara dengan Kasimun, 29 November 2013). Kasimun mengatakan bahwa warga bersikap biasa-biasa saja dan menjalankan aktifitas seperti biasa tanpa adanya rasa ketakutan berlebihan.

Setelah keadaan dinyatakan aman maka operasi penumpasan PKI di Kelurahan Wungu pada khususnya di hentikan. Warga di Kelurahan Wungu mulai melakukan 
aktifitas sehari-hari seperti biasanya sebelum ada Gerakan 30 September 1965 dan operasi penumpasan PKI. Suasana aman dan tentram ini membuat roda kegiatan berjalan semestinya. Hal ini di sampaikan Kasimun (Sumber: wawancara dengan Kasimun, 29 November 2013)yang menyatakan bahwa tidak ada perasaan takut dan was-was pada warga di Kelurahan Wungu. Hal senada juga dinyatakan oleh Sugiri (Sumber: wawancara dengan Sugiri, 15 November 2013). Sugiri menyatakan bahwa masyarakat di Kelurahan Wungu sudah tenang dan tentram setelah PKI di bubarkan.

Hal ini berkebalikan dengan pernyataan Djumani dan Paiman (Sumber: wawancara dengan Djumani, 29 November 2013). Mereka sepakat bahwa masyarakat di Kelurahan Wungu terutama masyarakat kecil masih trauma pada kejadian di Distrik. Muncul rasa takut pada tentara maupun polisi karena mereka menganggap tentara dan polisi adalah pihak yang bertanggung jawab atas penculikan warga saat penumpasan PKI berlangsung. Muncul juga rasa was-was jika bertemu dengan orang asing karena mereka menganggap bahwa orang asing tersebut adalah intel pemerintah yang dikirim untuk mematamatai kegiatan warga.

Hal ini dibenarkan oleh Mudzakir (Sumber: wawancara dengan Mudzakir, 10 November 2013) yang kemudian menambahi bahwa eks tapol dan keluarganya akan dipersulit dalam mencari pekerjaan sebagai Pegawai Negeri Sipil. Selain itu, eks tapol juga wajib absen di koramil minimal 1 bulan sekali selama di perlukan. Sependapat dengan itu, Danus (Sumber: wawancara dengan Danus, 29 November 2013) menambahi bahwa di Koramil terdapat catatan-catatan lengkap tentang siapa saja warga yang menjadi daftar tapol PKI.

Terdapat beberapa pendapat tentang psikologi sosial, yaitu pendapat dari Baron dan Bryne (2004) bahwa psikologi sosial adalah cabang psikologi yang berupaya untuk memahami dan menjelaskan cara berfikir, berperasaan, dan berperilaku individu yang dipengaruhi oleh kehadiran orang lain. Kehadiran orang lain itu dapat dirasakan secara langsung, diimajinasikan, ataupun diimplikasikan (Fattah Hanurawan, 2010: 1).

Dari beberapa pendapat diatas dapat ditarik benang merah bahwa psikologi sosial merupakan kajian tentang proses interaksi masyarakat. Dalam arti luas, interaksi mengacu kepada kenyataan bahwa respon seseorang seorang individu atau kelompok (isyarat, ucapan atau gerak jasmaniyah) merupakan stimulus bagi individu atau kelompok lainnya yang sebaliknya merespon individu atau kelompok pertama (Waseso dalam Muhammad Hanif, 2011: 63).

Dalam hal ini ditekankan bahwa kondisi psikologi sosial masyarakat di 
Kelurahan Wungu terkena dampak secara langsung dari peristiwa di Distrik yang mengakibatkan munculnya rasa takut dan was-was bila bertemu dengan orang asing maupun dengan tentara atau polisi pada tahun 1965-1998. Hal ini semakin berdampak besar karena terdapat alasan secara politis, yakni pendidikan politis selama 32 tahun pemerintahan Orde Baru, antara lain adanya Tap MPRS No. XXV/MPRS/1996.

\section{Kesimpulan}

Berdasarkan pembahasan diatas maka dapat disimpulkan bahwa pengaruh peristiwa Gerakan 30 September 1965 terhadap kondisi psikologi sosial masyarakat di Kelurahan Wungu 1965-1998 menunjukkan, munculnya perasaan ketakutan dan was-was pada warga masyarakat Kelurahan Wungu sejak tahun 1965-1998 yang di sebabkan oleh trauma akan peristiwa penangkapan beberapa warga masyarakat Kelurahan Wungu oleh intel Pemerintah. Ketakutan ini sangat dirasakan oleh warga masyarakat di Kelurahan Wungu apabila melihat tentara, Polisi, ataupun orang asing yang tidak mereka kenal, karena warga mengganggap tentara, polisi, dan orang asing tersebut merupakan intel dari pemerintah yang bertugas mengawasi warga Kelurahan Wungu.

Munculnya rasa ketakutan warga Kelurahan Wungu juga dirasakan dalam hal mencari pekerjaan. Muncul adanya diskriminasi kepada eks tapol dan keluarganya yang akan dipersulit dalam mencari pekerjaan sebagai Pegawai Negeri Sipil. Selain itu, eks tapol juga wajib absen di koramil minimal 1 bulan sekali selama di perlukan. Hal ini semakin berdampak besar karena terdapat alasan secara politis, yakni pendidikan politis selama 32 tahun pemerintahan Orde Baru.

\section{Saran}

1. Bagi Masyarakat Kelurahan Wungu

Diharapkan masyarakat Kelurahan Wungu ikut membantu dan berperan aktif dalam menjaga kerukunan dan keharmonisan dalam kehidupan sehari-hari terlepas dari sejarah masa lalu yang ada di Kelurahan Wungu.

2. Bagi Masyarakat Di Luar Kelurahan Wungu

Diharapkan masyarakat di luar Kelurahan Wungu ikut berperan serta dalam menjaga kerukunan dan keharmonisan dalam kehidupan ber masyarakat, terlepas dari sejarah masa lalu yang ada di Kelurahan Wungu dan sekitarnya.

3. Bagi Pemerintah Kabupaten Madiun

Diharapkan Pemerintah Kabupaten Madiun ikut berperan aktif dalam meningkatkan kesadaran sejarah warga di Kabupaten Madiun dengan cara memberikan penyuluhan sejarah lokal yang obyektif secara kontinu, agar warga tidak 
terjebak pada pemikiran subyektif tentang kasus Gestok.

4. Bagi Peneliti

Mengingat ada beberapa saksi kunci yang tidak berkenan untuk di wawancara, maka peneliti mengharapkan ada penelitian lanjutan dengan memperluas kesaksian sehingga dapat dihasilkan karya ilmiah yang lebih baik.

\section{Daftar Pustaka}

Basrowi dan Suwandi. 2008. Memahami Penelitian Kualitatif. Jakarta : Rineka Cipta

C.Ricklefs. 2008. Sejarah Indonesia Modern. Jakarta: Serambi

David G Myers. 2012. Psikologi sosial . Jakarta: Salemba Humanika

Elly M. Setiadi. 2006. Ilmu Sosial dan Budaya Dasar. Jakarta: Kencana

Fattah Hanurawan. 2010. Psikologi sosial . Bandung: PT Remaja Rosdakarya

Gerungan. 2004. Psikologi Sosial. Bandung: PT. Refika Aditama

H. B. Sutopo. 2002. Metodologi Penelitian Kualitatif. Surakarta: Sebelas Maret University Press

- 2006. Metodologi Penelitian Kualitatif Dasar Teori dan Terapannya Dalam Lapangan. Surakarta: Sebelas Maret University Press

Harry A. Poeze. 2011. Madiun 1948 : PKI Bergerak. Jakarta: Yayasan Pustaka Obor Indonesia
Husaini Usman dan Purnomo Setiadi Akbar. 2004. Metode Penelitian Sosial. Jakarta: PT. Bumi Aksara

Marwati Djoened Poesponegoro dkk. 1993. Sejarah Nasional Indonesia V. Jakarta: Balai Pustaka . 2008. Sejarah Nasional Indonesia VI. Jakarta: Balai Pustaka

Muhammad Hanif. 2011. Peranan Wanita Desa Soco Bendo Magetan Dalam Mengatasi Dampak Psikologi Sosial Pasca Madiun Affair 1948 dalam Agastya Vol. 01, No. 01, Januari 2011. Madiun: Pendidikan Sejarah IKIP PGRI Madiun

PEMKAB MADIUN. 1980. Sejarah Kabupaten Madiun. Madiun

Profil Kelurahan Wungu tahun 2012

Slamet Santoso. 2010. Teori-teori Psikologi Sosial . Bandung: PT. Refika Aditama

Takashi Shiraishi. 1997. Zaman Bergerak: Radikalisme Rakyat di Jawa. Jakarta: PT. Pustaka Utama Grafiti 